\title{
A CASE OF FIBROCYSTIC DISEASE OF THE PANCREAS WITH INTESTINAL OBSTRUCTION
}

\author{
BY \\ EMMANUEL LEVY \\ From the Department of Pathology, St. George's Hospital Medical School, London
}

(Received for Publication November 10, 1950)

Fibrocystic disease of the pancreas was first described by Landsteiner in 1905 , and it is of interest, that intestinal obstruction was one of the features of his case. Since then, and particularly in the past two decades, many well authenticated cases have been described.

Andersen (1938), described three clinicalsyndromes as being associated with essentially the same pathological lesion in the pancreas. The first was characterized by intestinal obstruction in the first week of life (meconium ileus); the second by respiratory infection in the first six months of life; and the third by the development of the coeliac syndrome in later childhood. The division into these types has been generally supported both by authors considering all phases of the disease (Andersen, 1939; Deem and McGeorge, 1941; Jeffrey, 1941; Wolman, 1942 ; Farber, 1942 and 1943; Markel, 1944; Menten and Middleton, 1944; Baggenstoss and Kennedy, 1945; Pugh, 1945; Andersen and Hodges, 1946; Bodian, 1946; Macgregor and Rhaney, 1948; Torgersen, 1948; Jones, 1949; Matheson, 1949; Andersen, 1949), and by those concerned only with meconium ileus (Dodd, 1936; Sobel, 1941; Sprenger, 1942; Farber, 1944a and b; Swenson and Ladd, 1945; Glanzmann, 1946; Hiatt and Wilson, 1948).

The case described here is remarkable for the occurrence of intestinal obstruction at the age of 7 months. It appears to be the first recorded instance in which this feature has developed so late in infancy.

\section{Case Report}

J.R., a boy aged 9 weeks, was referred to hospital on February 29, 1949, from a welfare centre which the mother had attended because of feeding difficulties. The birth weight was $6 \mathrm{lb} .9 \mathrm{oz}$. and the infant had been breast fed. From the age of 3 weeks there had been a persistent, troublesome cough with attacks of diarrhoea and failure to gain weight. On admission the weight was $7 \mathrm{lb} .7 \mathrm{oz}$. The stools appeared green and undigested but pathogenic bacteria were not isolated on culture. The urine was normal and the haemoglobin $76 \%$ (Haldane). Stool examinations were negative for trypsin, and radiographs of the chest showed catarrhal changes in both lungs. The diagnosis of fibrocystic disease of 


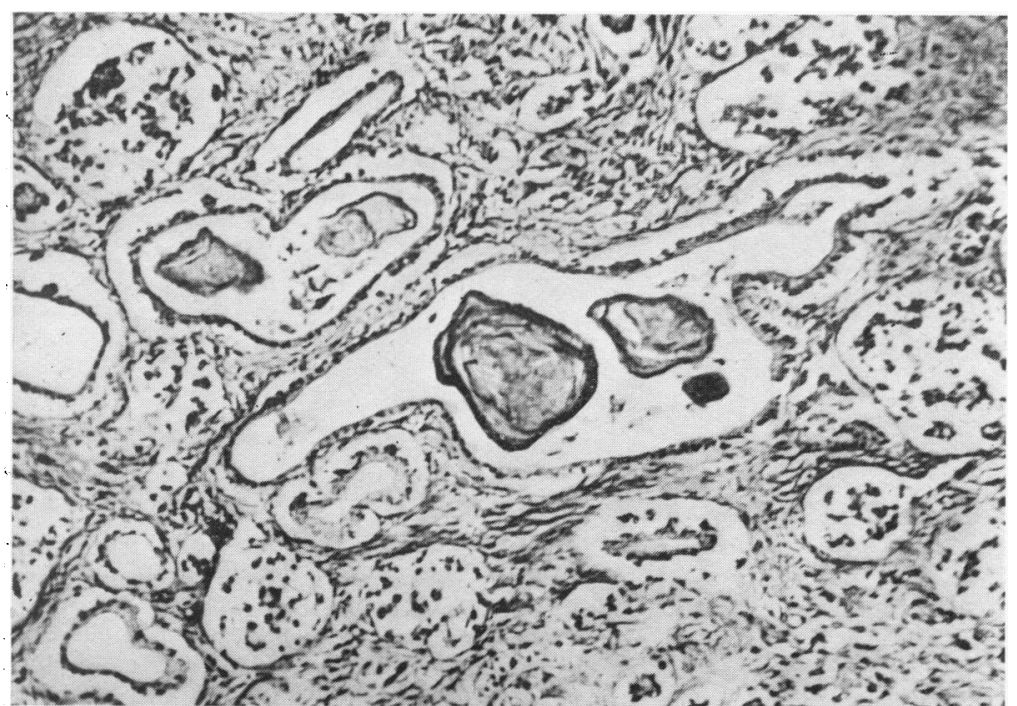

Fig. 2.-Section of the pancreas (Mallory's fibrous tissue stain. $\quad \times 110$ ).

small groups by broad bands of collagen. Cystic dilatation of the ducts was marked, and many contained desquamated epithelium and homogeneous eosinstaining material (Fig. 2). The clinical diagnosis of fibrocystic disease of the pancreas was thus confirmed. Histological changes in other organs were of a minor character and not relevant to this discussion. A histological examination of the gut was not made.

\section{Discussion}

In the Table a summary is given of the recorded cases of fibrocystic disease of the pancreas associated with intestinal obstruction and supported by post-mortem and histological studies. The cases of congenital intestinal obstruc-

the pancreas was made and the patient was discharged home. Breast feeding was continued until the age of 5 months when weaning began, and pancreatin (gr. 60 daily) was given throughout. Courses of penicillin were given on three occasions for exacerbations of the respiratory infection. Progress was satisfactory from the age of 4 months up to the terminal episode. The patient was readmitted to hospital on April 11, 1949, with a history of having vomited all feeds during the previous three days and absence of bowel action for four days. A tentative diagnosis of intussusception was made and an immediate laparotomy was performed. A small amount of straw-coloured fluid was present in the peritoneal cavity. The small gut was plum-coloured and distended, and there were haemorrhages at the root of the mesentery; the colon was contracted and empty. No cause for obstruction could be found, and the abdomen was closed without further interference. Convulsions occurred after the operation and the patient ilapsed into coma and died the next day.

Post-mortem Findings. The peritoneal cavity contained a small amount of fluid, and there were delicate fibrinous adhesions between the loops of bowel. The small intestine was distended and plum-coloured to within $12 \mathrm{~cm}$. of the ileo-caecal valve. Small haemorrhages were present in the mesentery and the contents of the distended gut were of a putty-like consistency. There was no evidence of volvulus, intussusception, or other organic obstruction. The transverse colon showed some gaseous distension but the remainder of the large bowel appeared collapsed (Fig. 1). The pancreas was somewhat firmer than normal, but the main pancreatic and bile ducts were patent. Apart from some pallor of the liver and kidneys the other organs were essentially normal. There was no evidence of bronchiectasis.

Histological examination of the pancreas showed a great increase in fibrous tissue, the acini being split into tion reported by Torkel (1905), Bullowa and Brennan (1919), Hughes (1922), Exalto (1924), Meltzer (1936), Burger (1938), and Adamson and Hild (1939) have not been included. Although some of these may have been due to fibrocystic disease of the pancreas, histological proof is lacking. Other reported cases have been excluded as the available evidence points to a different underlying pathology (Soldin, 1913; Fanconi, 1920; Frick, 1934; Denzer, 1941; Jeffrey, 1941 — second case; Sprenger, 1942-first case; and Hinden, 1950).

All the 55 accepted cases included in the Table occurred in the neonatal period; the obstructive element in all is therefore covered by the term meconium ileus. The presence of associated volvulus (cases 17, 41, 43, 44, and 54) can certainly be regarded as a secondary manifestation, and the presence of congenital bands (cases $4,18,42$, and 46) as coincidental. However, it is interesting to note the high incidence of atresia of the small gut, no fewer than nine of the 55 cases showing this abnormality (cases 5, 6, 10, 13, 14, 21, 24, 49, and 55). Andersen (1938) considered that such atresia was coincidental, but Zuelzer and Newton (1949) suggested that it was the direct result of the meconium ileus. They receive strong support from Lelong, Petit, Le Tan Vinh, and Borniche (1950) who produced striking histological evidence from examination of the intestinal wall in their case. They found replacement of the mucous membrane and muscle layers by granulation tissue which led to scar formation and secondary atresia.

In the case recorded here the only cause for the 
TABLE

Recorded Cases of Proved Fibrocystic Disease of the Pancreas with Intestinal Obstruction

\begin{tabular}{|c|c|c|c|c|c|c|}
\hline Case No. & \multicolumn{4}{|l|}{ Author } & $\begin{array}{l}\text { Age at Onset } \\
\text { Birth } \\
\text { 2 days } \\
\text { Birth }\end{array}$ & Associated Abnormalities \\
\hline $\begin{array}{r}1 \\
2 \\
3 \\
4 \\
5 \\
6 \\
7 \\
8 \\
9 \\
10 \\
11 \\
12 \\
13 \\
14 \\
15 \\
16 \\
17 \\
18 \\
19 \\
20 \\
21 \\
22 \\
23 \\
24 \\
25 \\
26 \\
27 \\
28 \\
29 \\
30 \\
31 \\
32 \\
33 \\
34 \\
35 \\
36 \\
37 \\
38 \\
39 \\
40 \\
41 \\
42 \\
43 \\
44 \\
46 \\
47 \\
48 \\
49 \\
50 \\
51 \\
52 \\
53 \\
54 \\
55\end{array}$ & $\begin{array}{l}\text { Bronaugh and Lattimer, } 1940 \\
\text { Deem and McGeorge, } 1941 \\
\text { Sobel, } 1941 \text {.. .. } \\
\text { Jeffrey, 1941 . } \\
\text { Hurwitt and Arnheim, } 1942 \\
\text { Flax, Barnes, and Reichert, } 1942 \\
\text { Sprenger, 1942 } \\
\text { Kaufmann and Chamberlin, } 1943 \\
\text { Menten and Middleton, 1944 } \\
\text { Baggenstoss and Kennedy, } 1945 \\
\text { Wissler and Zollinger, } 1945 \\
\text { Bodian, 1946 .. .. } \\
\text { Glanzmann, 1946, and Riniker, } \\
\text { Andersen and Hodges, 1946 } \\
\text {. }\end{array}$ & $\begin{array}{l}\cdots \\
\cdots \\
\cdots \\
\cdots \\
\cdots \\
\cdots \\
\cdots \\
\cdots \\
\cdots \\
\cdots\end{array}$ & $\begin{array}{l}\cdots \\
\cdots \\
\cdots \\
\cdots \\
\cdots \\
\cdots \\
\cdots \\
\cdots \\
\cdots \\
\cdots \\
\cdots\end{array}$ & 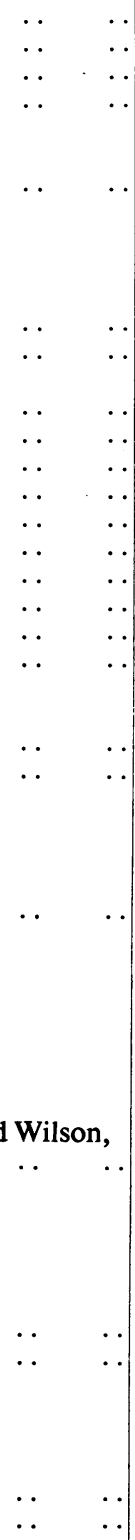 & $\begin{array}{l}\text { Birth } \\
\text { 2 days } \\
\text { Birth } \\
\text { Neonatal } \\
\text { Neonatal } \\
\text { Neonatal } \\
\text { Neonatal } \\
\text { Neonatal } \\
\text { Neonatal } \\
\text { Neonatal } \\
\text { Neonatal } \\
\text { Birth } \\
\text { Congenital } \\
\text { Congenital } \\
\text { Birth } \\
\text { Neonatal } \\
\text { Birth } \\
\text { Birth } \\
\text { Birth } \\
\text { Birth } \\
\text { Birth } \\
\text { Neonatal } \\
\text { Birth } \\
\text { Neonatal } \\
\text { Neonatal } \\
\text { Neonatal } \\
\text { Birth } \\
\text { Neonatal } \\
\text { Neonatal } \\
\text { Neonatal } \\
\text { Neonatal } \\
\text { Neonatal } \\
\text { 1 day } \\
\text { Birth } \\
\text { Birth } \\
\text { Birth } \\
2 \text { days } \\
2 \text { days } \\
\text { 2 days } \\
\text { 1 day } \\
\text { 2 days } \\
\text { 3 days } \\
\text { 1 day } \\
\text { 1 1 days } \\
\text { 2 days } \\
2 \text { days } \\
4 \text { days } \\
\text { Birth } \\
\text { Birth } \\
\text { Birth } \\
\text { Birth } \\
\text { Birth } \\
\text { Birth } \\
\text { Birth } \\
\text { Birth } \\
\end{array}$ & $\begin{array}{l}\text { Atresia small gut } \\
\text { Cirrhosis of liver } \\
\text { Atresia small gut } \\
\text { Atresia small gut } \\
\text { Volvulus } \\
\text { Fibrous band } \\
\text { Meckel's diverticulum } \\
\text { Atresia small gut }\end{array}$ \\
\hline
\end{tabular}


intestinal obstruction was the abnormal state of the intestinal contents. Farber (1944b) stated that meconium ileus without pancreatic disease might be due to volvulus, stenosis of the ileo-caecal valve, or biliary obstruction: none of these causes was operative in the present case. Analysis of the intestinal contents found at necropsy gave normal figures for total and split fat (total fat $55 \cdot 3 \mathrm{~g}$. per $100 \mathrm{~g}$. dried faeces; $74 \%$ of the fat was split). The usual findings in this disease are increased total fat with a high percentage of unsplit fat (Shohl, May, and Shwachman, 1943; Andersen, 1945). Moreover the stools had not been bulky or malodorous. The absence of such abnormalities may not be surprising in view of the continuous administration of pancreatin for the four months before death. A high faecal nitrogen content is also characteristic of this disease (Shohl et al., 1943), but owing to the rapidity with which death took place in the terminal episode no other biochemical studies were carried out. Despite the failure to correlate the altered physical state of the intestinal contents with any specific chemical abnormality, it is reasonably certain that the alteration in this case must be ascribed to the pancreatic lesion.

It is universally agreed that in meconium ileus the obstruction is the direct result of the abnormal physical character of the meconium. Further, in cases uncomplicated by obstructing bands, atresia or volvulus, the morbid anatomical picture is uniformly that of a distended ileum only slightly affecting the terminal loop, and a contracted empty large bowel (Dodd, 1936; Sobel, 1941; Sprenger, 1942; Kaufmann and Chamberlin, 1943; Farber, 1944b; Riniker, 1946). Except for the age of the patient the case recorded here closely parallels the features of meconium ileus. There are the same lesion in the pancreas, a similar change in the physical character of the intestinal contents, and an identical morbid anatomical picture.

Farber (1942, 1944a and b) pointed out that pancreatic achylia in the late intra-uterine period causes meconium ileus, whereas if it develops later in life it produces the coeliac syndrome. It should not be surprising, therefore, that two clinical conditions resulting from the same basic pathological lesion show close similarity although occurring at different ages.

Hiatt and Wilson (1948) in discussing meconium ileus suggest that all gradations occur from partial or subacute obstruction to complete obstruction, and that in some cases obstruction is relieved spontaneously by the passage of meconium plugs. It seems clear that there is a transition from the cases occurring early in infancy in which the obstructive features predominate (meconium ileus) to the cases developing later in which the features of steatorrhoea (the 'coeliac syndrome') dominate the clinical picture. The difference in the clinical features at the different ages is no doubt related to the increased muscular vigour, including the power of intestinal peristalsis, in the older children. In these more vigorous children the bowel is capable of propelling the putty-like faeces through the ileo-caecal valve, but even in these cases intestinal stasis develops and may well be responsible for the vomiting which is such a prominent clinical feature. It is in the younger and more debilitated cases that complete obstruction is liable to supervene.

Rasor and Stevenson (1941) describe a boy with fibrocystic disease of the pancreas who died at the age of 1 year with a combination of respiratory infection and coeliac syndrome. Vomiting was a particularly troublesome feature, and at necropsy the intestinal contents were found to be of a puttylike consistency. Unfortunately most authors do not stress the putty-like character of the intestinal contents in similar cases. It seems likely that such a faecal abnormality is common in the coeliac phase of fibrocystic disease of the pancreas.

In the case recorded here intestinal obstruction developed at the unusually late age of 7 months when the patient had already entered the coeliac phase of the disease, a phase rarely encountered before the age of 1 year. The case thus forms a link between the classical 'meconium ileus' of the neonatal period and the coeliac phase of later childhood. The possibility of intestinal obstruction at this age, even when volvulus is present, being due to an altered physical state of the bowel contents with fibrocystic disease of the pancreas as its underlying pathology, should be borne in mind.

\section{Summary}

A case of fibrocystic disease of the pancreas is described. The patient died from intestinal obstruction at the age of 7 months.

The relation between meconium ileus and the coeliac phase of this disease is discussed.

Attention is drawn to the possibility of overlooking fibrocystic disease of the pancreas as a cause of intestinal obstruction after the first few days of life.

The literature on fibrocystic disease of the pancreas with intestinal obstruction is reviewed.

I wish to thank Professor Theodore Crawford for invaluable assistance in the preparation of this paper, and Dr. Ursula James for permission to use the clinical notes.

\section{REFERENCES}

Adamson, E. W., and Hild, J. R. (1939). J. Amer. med. Ass., 112, 2275. 
Andersen, D. H. (1938). Amer. J. Dis. Child., 56, 344. (1939). J. Pediat., 15, 763.

—— (1945). Amer. J. Dis. Child., 69, 221.

- - (1949). Proc. roy. Soc. Med., 42, 25.

—, and Hodges, R. G. (1946). Amer. J. Dis. Child., 72, 62 .

Baggenstoss, A. H., and Kennedy, R. L. J. (1945). Amer. J. clin. Path., 15, 64.

Blackfan, K. D., and May, C. D. (1938). J. Pediat., 13, 627.

Bodian, M. (1946). Archives of Disease in Childhood, 21, 179.

Bronaugh, W., and Lattimer, R. D. (1940). Amer. J. Dis. Child., 60, 1371.

Bullowa, J. G., and Brennan, R. E. (1919). J. Amer. med. Ass., 73, 1882.

Burger, P. G. (1938). Gynéc. et Obstét., 37, 176.

Deem, H., and McGeorge, M. (1941). N.Z. med. J., 40, 155 .

Denzer, B. S. (1941). Amer. J. Dis. Child., 62, 1114.

Dodd, K. (1936). J. Pediat., 9, 486.

Exalto, J. (1924). Dtsch.Z. Chir., 189, 52.

Fanconi, G. (1920). Virchows Arch., 229, 207.

Farber, S. (1942). Amer. J. Dis. Child., 64, 953.

- (1943). New Engl. J. Med., 229, 653.

- (1944a). Arch. Path., Chicago, 37, 238.

- (1944b). J. Pediat., 24, 387.

Flax, L. J., Barnes, M., and Reichert, J. L. (1942). Ibid., 21, 475.

Frick, P. (1934). Indian J. Paediat., 1, 223.

Glanzmann, E. (1946). Ann. paediatr., Basel, 166, 289.

-, and Berger, H. (1950). Ibid., 175, 33.

Hiatt, R. B., and Wilson, P. E. (1948). Surg. Gynec. Obstet., 87, 317.

Hinden, E. (1950). Archives of Disease in Childhood, 25, 99 .

Hughes, E. E. (1922). Brit. J. Child. Dis., 19, 32.
Hurwitt, E. S., and Arnheim, E. E. (1942). Amer. J. Dis. Child., 64, 443.

Jeffrey, F. W. (1941). Canad. med. Ass. J., 45, 224.

Jones, G. G. (1949). Lancet, 1, 651.

Kaufmann, W., and Chamberlin, D. B. (1943). Amer. J: Dis. Child., 66, 55.

Kornblith, B. A., and Otani, S. (1929). Amer. J. Path., 5, 249.

Landsteiner, K. (1905). Zbl. allg. Path. path. Anat., 16, 903.

Lelong, M., Petit, P., Le Tan Vinh, and Borniche (1950). Arch. franç., Pédiat., 7, 225.

Macgregor, A. R., and Rhaney, K. (1948). Archives of Disease in Childhood, 23, 56.

Markel, I. J. (1944). J. Indiana med. Ass., 37, 674.

Matheson, W. J. (1949). Brit. med. J., 2, 206.

Meltzer, S. (1936). Canad. med. Ass. J., 34, 186.

Menten, M. L., and Middleton, T. O. (1944). Amer. J. Dis. Child., 67, 355.

Pugh, D. G. (1945). Amer. J. med. Sci., 210; 681.

Rasor, R., and Stevenson, C. (1941). Rocky Mtn. med. $J ., 38,218$.

Riniker, P. (1946). Ann. paediatr., Basel, 166, 314.

Shohl, A. T., May, C. D., and Shwachman, H. (1943). J. Pediat., 23, 267.

Sobel, I. P. (1941). Amer. J. Dis. Child., 62, 1114.

Soldin, M. (1913). Jb. Kinderheilk., 77, 453.

Sprenger, F. (1942). Virchows Arch., 309, 644.

Swenson, O., and Ladd, W. E. (1945). New Engl. J. Med., 233, 660.

Torgersen, O. (1948). Acta. path. microbiol. scand., $25,124$.

Torkel, K. (1905). Dtsch. med. Wschr., 31, 344.

Wissler, H., and Zollinger, H. U. (1945). Helv. paediat. Acta, Suppl. 1,

Wolman, I. J. (1942). Amer. J. med. Sci., 203, 900.

Zuelzer, W. W., and Newton, W. A. (1949). Pediatrics, $4,53$. 